\title{
Two Spectrophotometric Assays for Dopamine Derivatives in Pharmaceutical Products and in Biological Samples of Schizophrenic Patients Using Copper Tetramine Complex and Triiodide Reagent
}

\author{
F. A. Nour El-Dien, ${ }^{1,3}$ M. A. Zayed, ${ }^{2}$ Gehad G. Mohamed, ${ }^{1}$ and Reham G. El-Nahas ${ }^{3 *}$ \\ ${ }^{1}$ Chemistry Department, Faculty of Science, Cairo University, Giza 12613, Egypt \\ ${ }^{2}$ Chemistry Department, Faculty of Education of Girls, El-Qassem Borida, Saudi Arabia \\ ${ }^{3}$ Microanalytical Center, Faculty of Science, Cairo University, Giza 12613, Egypt
}

Received 30 March 2004; revised 2 August 2004; accepted 24 August 2004

\begin{abstract}
Two simple, rapid, and sensitive spectrophotometric methods are proposed for the determination of levodopa (LD). The first method is based on coupling of 4-aminoantipyrine (4-AAP) with one of the dopamine derivatives (LD, CD) to give a new ligand that reacts with copper tetramine complex to give intensely colored chelates. The colored products are quantified spectrophotometrically at 525 and $520 \mathrm{~nm}$ for LD and CD, respectively. The optimization of the experimental conditions is described. The method has been used for the determination of 19.7-69.0 and 18.1-54.3 $\mu \mathrm{g} \mathrm{mL}-1$ of $\mathrm{LD}$ and CD, respectively. The accuracy of the method is achieved by the values of recovery $(100 \pm 0.2 \%)$ and the precision is supported by the low standard deviation $(S D=0.17-0.59)$ and relative standard deviation $(\mathrm{CV}=0.4 \%-1.54 \%)$ values. The second method is based on the formation of ion-pair iodinated inner sphere or outer sphere colored complexes between the LD and triiodide ions at $\mathrm{pH} 5$ and room temperature $\left(23 \pm 3^{\circ} \mathrm{C}\right)$. This method has been used for the determination of $\mathrm{LD}$ within the concentration range $39.44-78.88 \mu \mathrm{g} \mathrm{mL}^{-1}$ with $\mathrm{SD}=0.22-0.24$ and recovery percent $=100 \pm 0.3 \%$. The sensitivity of the two methods is indicated by Sandell's sensitivity of $0.014-0.019 \mathrm{~g} \mathrm{~cm}^{-2}$. The results of the two methods are compared with those of the official method. The interference of common drug additives, degradation products, and excipients was also studied. The proposed methods were applied successfully to the determination of the LD-CD synthetic mixture and Levocare drug. The determination of LD in urine of some schizophrenic patients was applied with good precision and accuracy. The reliability of the methods was established by parallel determinations against the official British pharmacopoeia method.
\end{abstract}

\section{INTRODUCTION}

The dopamine derivatives participate in the regulation of a wide variety of physiological functions in the human body and in medication life depending on their structures (Figure 1).

Hormones act as chemical messengers controlling the activity of living things. They are released in small amounts in the blood stream from a number of vital sites especially some brain regions. Dopamine was recognized as a neurotrasmitter in its own right but the demonstration of its nonuniform distribution in the brain suggested that it might have a specific functional role of dopamine [1]. It had an important role in the pathogenesis of drug treatment of certain brain diseases, Parkinson's disease, and schizophrenia. Parkinson's disease was associated with decrease of dopamine concentration in the brain (Nozaki Y, Abe T, Takahashi S,
1995), [2]. So it must be medicated with drugs containing $\mathrm{LD}$ combined with a certain amount of $\mathrm{CD}$, which makes LD available for transport to the brain and converted to dopamine in the basal ganglia [3, 4]. The brain of a schizophrenic patients produces more dopamine, especially in the striatum of the brain, than the normal brain (see http://serendip.brynmawr.edu/bb/neuro/ neuro98/202s98-paper1/Frederickson.html). In this case, the drug used blocks dopamine receptors in the brain. The increasing awareness of the biological significance of dopamine derivatives has promoted a great deal of research into their detection and quantitative determination [5, 6] (Stores W, Putters J, Van Rijn HJM, 1987). Several methods have been described in the literature for dopamine determination in biological samples and pharmaceutical formulation like chromatography and amperometry $[7,8]$. Ratiospectra derivative spectrophotometry procedure was applied on detection of binary mixtures of 
<smiles>[R]Cc1ccc(O)c(O)c1</smiles>

$\mathrm{LD} ; \mathrm{R}=\mathrm{CH}\left(\mathrm{NH}_{2}\right) \mathrm{COOH}$

$\mathrm{CD} ; \mathrm{R}=\mathrm{C}\left(\mathrm{CH}_{3}\right)\left(\mathrm{NHNH}_{2}\right) \mathrm{COOH}$

FIgURE 1. Structural formulae of the investigated dopamines.

LD and benserazide in their pharmaceutical preparations as well as other compounds frequently associated with them [9]. Many hospital laboratories are now adopting the HPLC method for measuring catecholamines (Musso NR, Vergassola C, Pende A, Lotti G, 1990), (Kitahashi T, Ohba Y, Sawada Y, Suzuki H, 1991) [10, 11]. However, HPLC technique is very time-consuming and restricted to the highly specialized, so many spectrophotometric procedures were recommended for dopamine detection using ninhydrin (Biryuk LA, Petrenko VV, Zorya BP, 1992) and chloramine-T (Nagaraja P, Murthy KCS, Yathirajan HS, Mohan BB, 1998).

The purpose of the present work is to describe the development of two simple, sensitive, and rapid spectrophotometric methods for the determination of $\mathrm{LD}, \mathrm{CD}$, and $\alpha$-MD depending upon the formation of their colored copper mixed ligand chelates and colored ion-pair outer sphere and/or inner sphere iodinated compounds with triiodide ion. Different experimental conditions are carefully studied before applying Beer's law. The two methods were applied for determining dopamine derivatives in pure, pharmaceutical, and urine samples.

\section{EXPERIMENTAL}

\section{Apparatus}

All absorption spectra measurements were recorded using a Milton Roy Spectronic 601 and an automated Perkin Elmer Lambda 20 UV/Vis spectrophotometer in the wavelength range $200-900 \mathrm{~nm}$. The $\mathrm{pH}$ adjustment was done using a Titrino Metrohm 716 DMS, connected to a Metrohm stirrer. This instrument has a combined glass and reference electrodes used for $\mathrm{pH}$ measurements. For selecting accurate microliter volumes, the calibrated micro-pipette (BRAND) of disposable plastic tips was used in the range $100-1000 \mu \mathrm{L}$.

\section{Materials}

All reagents were of the analytical grade. LD and CD were purchased from El-Naser Pharmaceutical Company. The 4-AAP was obtained from Fluka Chemie AG. Copper sulphate $\left(\mathrm{CuSO}_{4} \cdot 5 \mathrm{H}_{2} \mathrm{O}\right)$ was purchased from Sigma, iodine and potassium iodide, ammonia solution $33 \%(\mathrm{v} / \mathrm{v})$, and sodium hydroxide were supplied from BDH. Glacial acetic acid, boric acid and phosphoric acid (90\%) were purchased from Aldrich.

\section{Reagents}

$10^{-2} \mathrm{M}$ stock solutions of $\mathrm{LD}$ and $\mathrm{CD}$ were prepared in deionized water. $10^{-3} \mathrm{M}$ solutions of these drugs were obtained by accurate dilution. All dopamine derivative solutions were stored in dark bottles at $4^{\circ} \mathrm{C}$ in the refrigerator to avoid their oxidation [12]. $10^{-2}-10^{-3} \mathrm{M}$ solutions of copper sulphate were obtained by accurate dilution from $0.1 \mathrm{M}$ acidified stock solution $\left(0.3 \mathrm{~mL} \mathrm{H}_{2} \mathrm{SO}_{4}\right)$ that standardized by recommended procedure (Yoe, Jones, 1944). The ammonia solution of $3.5 \mathrm{M}$ and universal buffer of acetic, boric, and phosphoric acids $(0.04 \mathrm{M}$ of each in one liter mixture of various $\mathrm{pH}$ values) were used for $\mathrm{pH}$ adjustment of the drug reagents reaction media. $0.1 \mathrm{M}$ solutions of interfering materials (glucose, maltose, 2-nitrophenol, pyrogallol, resorcinol, pyrocatechol, urea, salicylic acid, paracetamol, and ascorbic acid) were prepared by dissolving appropriate weight in $25 \mathrm{~mL}$ deionized water. The $10^{-2}-10^{-3} \mathrm{M}$ solutions of the interfering materials were prepared by accurate dilution from the stock solution.

\section{Procedures}

(I) An aliquot containing 19.7-69 or 18.1$54.3 \mu \mathrm{g} \mathrm{mL}^{-1}$ of $\mathrm{LD}$ or $\mathrm{CD}$, respectively, was transferred to a $10 \mathrm{~mL}$ measuring flask, followed by $0.3 \mathrm{~mL}$ from $10^{-2} \mathrm{M}$ copper sulphate mixed with $0.24 \mathrm{~mL}$ of $3.5 \mathrm{M}$ ammonia to have $\mathrm{pH} 10.5$ and $0.2 \mathrm{~mL}$ of $0.0295 \mathrm{M} 4$-AAP. The blue to violet color mixture was completed to $10 \mathrm{~mL}$. The mixtures were shaken well and allowed to stand at $22 \pm 3^{\circ} \mathrm{C}$ for 10 and 12 minutes, and the absorbance was measured at 525 and $520 \mathrm{~nm}$ against deionized water as a blank for LD and CD, respectively. The calibration curves were obtained applying the same procedure using standard drug solutions.

(II) An aliquot containing 39-79 $\mu \mathrm{g} \mathrm{mL}^{-1}$ of $\mathrm{LD}$ was transferred to a $10 \mathrm{~mL}$ measuring flask, followed by addition of $0.1 \mathrm{~mL}$ of $0.1 \mathrm{M} \mathrm{I}_{3}^{-}$reagent and universal buffer of pH 5 up to the mark. The mixture was shaken well and allowed to stand for 6 minutes at $23 \pm 2^{\circ} \mathrm{C}$. The absorbance of the colored reaction product was measured at $500 \mathrm{~nm}$. The calibration curve for LD was obtained applying the same procedure using standard drug solutions.

\section{Analysis of dosage forms}

The contents of tablets of Levocare, for LD (250 mg), were weighed, powdered, and then transferred to a $100 \mathrm{~mL}$ beaker containing $50 \mathrm{~mL}$ of deionized water. The solution was filtered in Whatman No 1 filter paper, washed well, and the filtrate was transferred into a $100 \mathrm{~mL}$ volumetric flask and completed to the mark. An aliquot of the solution containing $50 \mu \mathrm{g} \mathrm{mL}^{-1}$ of the analyte was transferred to a $10 \mathrm{~mL}$ measuring flask and analyzed applying either procedure (I) or procedure (II). 


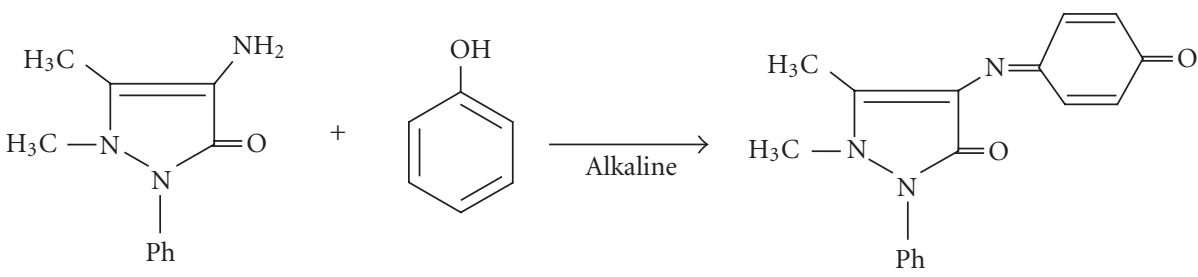

FIgURE 2. Coupling reaction between phenyl and 4-AAP.
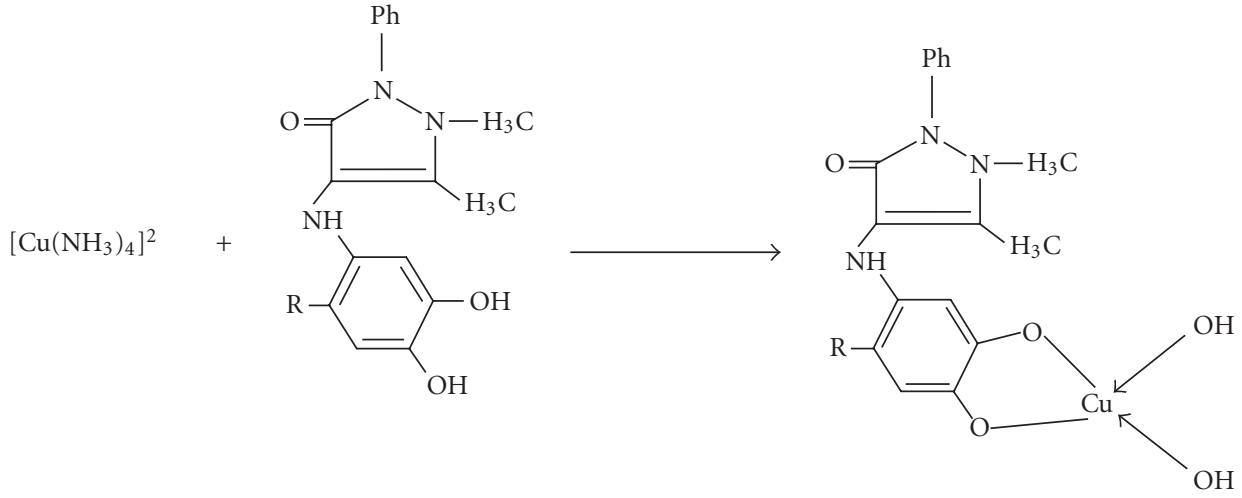

$\mathrm{LD} ; \mathrm{R}=\mathrm{CH}_{2} \mathrm{CH}\left(\mathrm{NH}_{2}\right) \mathrm{COOH}$

$\mathrm{CD} ; \mathrm{R}=\mathrm{CH}_{2} \mathrm{C}\left(\mathrm{CH}_{3}\right)\left(\mathrm{NHNH}_{2}\right) \mathrm{COOH}$

SCHeme 1

\section{Analysis of synthetic mixture of $L D$ and $C D$}

An aliquot of a synthetic mixture of $\mathrm{LD}$ and $\mathrm{CD}$ in a ratio of $10: 1$, as that found in Levocare drug tablets, was analyzed for LD by applying procedures (I) and (II) to detect what the effect of $\mathrm{CD}$ is on $\mathrm{LD}$ determination.

\section{Urine analysis}

The urine samples were collected from 6 normal people and 5 schizophrenic patients and transferred into wellcleaned sample tubes. To $20 \mathrm{~mL}$ urine samples, one drop of $3 \mathrm{~N} \mathrm{HCl}$ was added to get a final $\mathrm{pH}$ of 3 , and a rapid centrifuge for 30 seconds must be done to get homogeneity of the sample. The urine samples of schizophrenic patients were analyzed for LD in comparison with normal ones.

\section{RESULTS AND DISCUSSION}

The theory of drug reactions with reagents is illustrated as follows.

\section{In procedure (I)}

Different colorimetric methods described for phenol determination (Emerson E, 1943), (Chen Y, Wang S, Zhou T, 1998), (Frank M, Matthias O, 1995), [13, 14] are based on the reaction between phenols and 4-AAP to form antipyrine dyes where 4-AAP is found to be the most sensitive, fast, and precise colorimetric reagent. 4-AAP reacts with phenolic-type compounds according to the reaction shown in Figure 2. The reaction product may be any color from red to purple depending on the phenolic-type compounds involved.

Applying the molar ratio method, it is found that catecholamines form a dye-coupled product with 4-AAP in the ratio $1: 1 \mathrm{Cu}:$ dye products. The reaction may proceed as given in Scheme 1:

$$
\mathrm{Cu}^{2+}+4 \mathrm{NH}_{3} \rightleftarrows\left[\mathrm{Cu}\left(\mathrm{NH}_{3}\right)_{4}\right]^{2+} \text {. }
$$

The solid products of this reaction are separated and characterized using different tools like elemental analysis, IR, magnetic, UV-Vis and thermal analysis and recently published [15].

\section{In procedure (II)}

Iodine in iodide medium forms two species in equilibrium to each other:

$$
\mathrm{I}^{-}+\mathrm{I}_{2} \rightleftarrows \mathrm{I}_{3}^{-} .
$$

Iodine is amphoteric in nature, that is, it can act as an electron donor or acceptor due to its molecular orbital structure $[16,17]$. The phenolic groups of dopamine may be oxidized and iodinated with iodine which acts as an electron acceptor due to the following reaction:

$$
\mathrm{R}_{1} \mathrm{R}_{2} \mathrm{~L}(\mathrm{OH})_{2}+2 \mathrm{I}_{2} \rightleftarrows \mathrm{R}_{1} \mathrm{R}_{2} \mathrm{~L}(\mathrm{OI})_{2}+2 \mathrm{HI}
$$




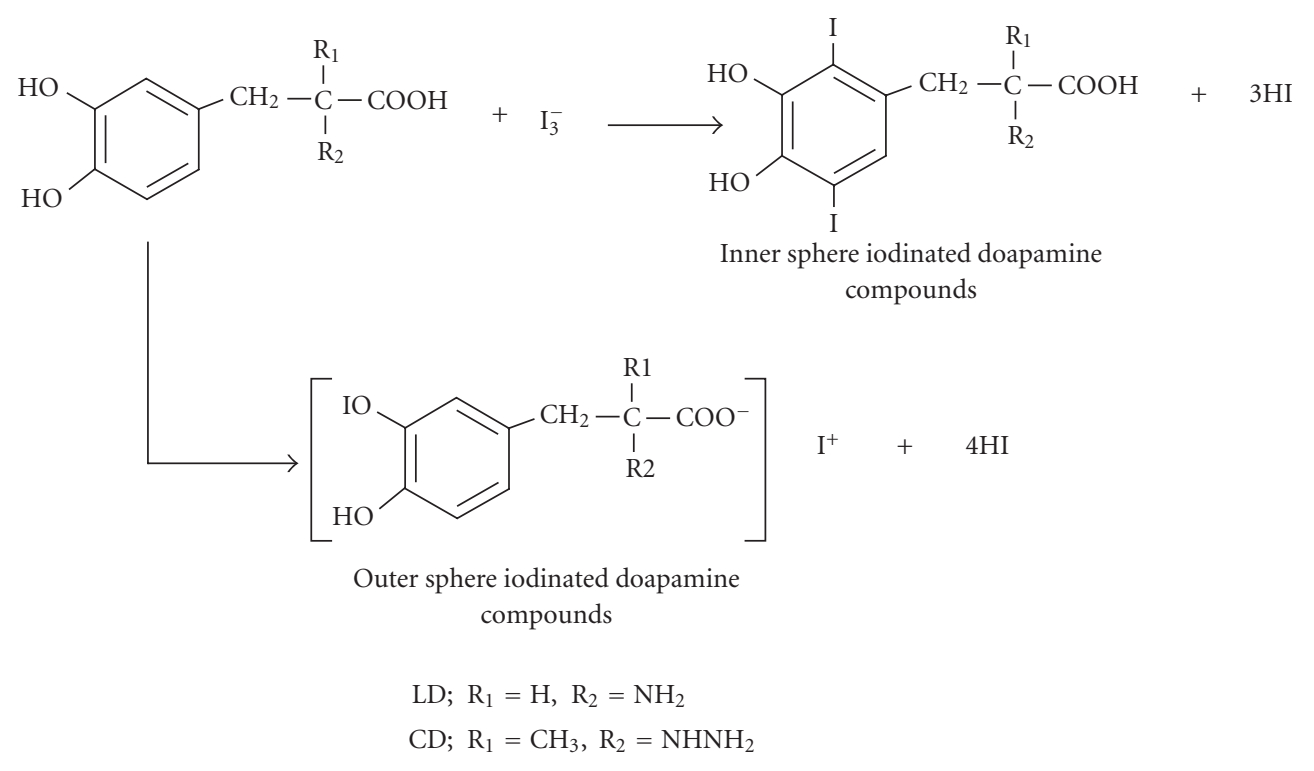

SCHeme 2

$\mathrm{I}_{3}^{-}$can react with LD by formation of inner and/or outer sphere complexes [17] as shown in Scheme 2.

The separated iodinated solid products were investigated using different tools and the results are under preparation for publication.

\section{Determination of $L D$ and $C D$ using $C u$ (II) complex and 4-AAP}

Optimum conditions affecting the reaction of LD and $\mathrm{CD}$ with $\mathrm{Cu}$ (II) tetramine complex and 4-AAP were studied carefully. The effect of $\mathrm{pH}$ was studied in the $\mathrm{pH}$ range of 9.5-12 using ammonia solution $(3.5 \mathrm{M})$ as shown in Figure 3. From the data it was found that the $\mathrm{pH}$ of 10.5 is the most suitable for microdetermination of the drugs where the complex is formed without any turbidity and it gave the highest absorbance. The stoichiometric ratio was performed using the molar ratio method and it was found to be $1: 1: 1 \mathrm{Cu}^{+2}: 4$-AAP : drug (Issa and Amin, 1996). Figure 4 shows the effect of time on the reaction of dopamine derivatives using procedure (I). The time needed for complete formation of metal complexes is 10 and 12 minutes to develop its maximum absorbance at room temperature $\left(23 \pm 2^{\circ} \mathrm{C}\right)$ in case of $\mathrm{LD}$ and $\mathrm{CD}$, respectively. The sequence of addition was studied and found to have the order $\mathrm{Cu}$ (II) tetramine complex, dopamine derivative, and then 4-AAP.

Under optimum conditions, a correlation was obtained between absorbance (A) and the concentration (C) over the range $19.7-69.0$ and $18.1-54.3 \mu \mathrm{g} \mathrm{mL}^{-1}$ of LD and $\mathrm{CD}$, respectively. The apparent molar absorptivity, Sandell sensitivity, standard deviation (SD), and coefficient of variation $(\mathrm{CV})$ for each drug are tabulated in Table 1. The apparent molar absorptivity of the resulting colored products was found to be $2.4 \times 10^{3}$ and

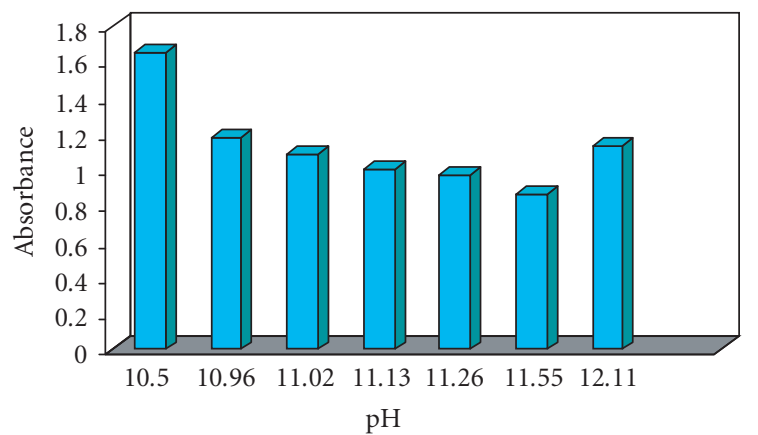

(a)

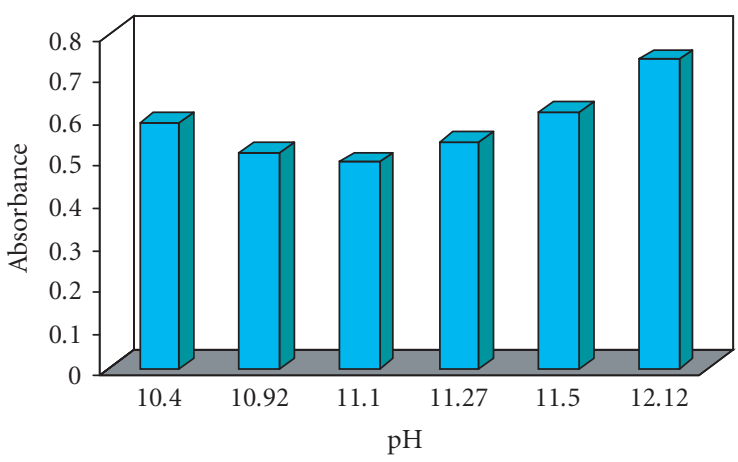

(b)

FIgURE 3. Clustered column showing relation between $\mathrm{pH}$ and absorbance in case of (a) LD-copper (II) complex and (b) CDcopper (II) complex.

$1.7 \times 10^{3} \mathrm{~L} \mathrm{~mol}^{-1} \mathrm{~cm}^{-1}$, whereas Sandell sensitivities are 0.014 and $0.019 \mathrm{~g} \mathrm{~cm}^{-2}$ for LD and CD, respectively. The correlation coefficient was found to be 0.999 and 0.995 , 
TABLE 1. Statistics for the recovery of $\mathrm{LD}$ and CD with copper (II) complex and 4-AAP, and LD with $\mathrm{I}_{3}^{-}$.

\begin{tabular}{lccc}
\hline Parameters & $\begin{array}{c}\text { LD } \\
\text { (procedure }(\mathrm{I}))\end{array}$ & $\begin{array}{c}\text { CD } \\
\text { (procedure (I)) }\end{array}$ & $\begin{array}{c}\text { LD } \\
\text { (procedure (II)) }\end{array}$ \\
\hline Detection range $(\mu \mathrm{g} / \mathrm{mL})$ & $19.72-69.02$ & $18.1-54.3$ & $39.44-78.88$ \\
Correlation coefficient & 0.999 & 0.995 & 0.999 \\
Sandell sensitivity & 0.014 & 0.019 & 0.026 \\
Molar absorptivity & $2.4 \times 10^{3}$ & $1.8 \times 10^{3}$ & $5.1 \times 10^{3}$ \\
$\quad\left(\mathrm{~L} \mathrm{~mol}^{-1} \mathrm{~cm}^{-1}\right)$ & 0.174 & 0.256 & 0.239 \\
SD & 0.89 & 0.68 & 0.54 \\
CV $(\%)$ & 3.0 & 3.0 & 3.0 \\
Number of replicates $v_{1}$ & 4.0 & 3.0 & 3.0 \\
Number of replicates $v_{2}$ & 6.58 & 7.07 & 6.78 \\
F test & 6.59 & 9.28 & 9.28 \\
$F^{*}$ test & 9.0 & 4.0 & 4.0 \\
Number of replicates $v_{1}$ & 0.565 & 0.191 & 0.865 \\
$t$ test & 2.262 & 2.776 & 2.776 \\
$t^{*}$ test & & & \\
\hline
\end{tabular}

$\mathrm{F}^{*}$ test is the values for $\mathrm{V}$ as degree of freedom for various confidence levels.

$t^{*}$ test is the values for $\mathrm{V}$ as degree of freedom for $95 \%$ confidence level.

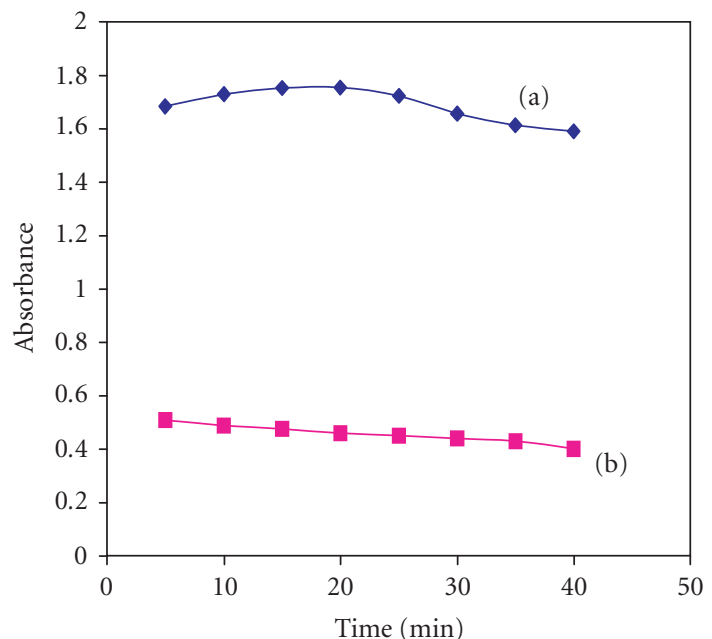

Figure 4. Effect of time on the absorbance of (a) LD and (b) CD with copper tetramine and 4-AAP.

while the SD is 0.174 and 0.256 for $\mathrm{LD}$ and $\mathrm{CD}$, respectively. The low values of CV and SD indicate the high accuracy, precision, and reproducibility of the proposed method to determine dopamine derivatives.

\section{Determination of LD using $\mathrm{I}_{3}^{-}$ion as oxidizing agent}

The principle underlying the determination of the important compound LD depends upon the reactions with iodine-triiodide under proper conditions (Scheme 2). The produced colored compound is investigated photometrically. This work involves the study of these color reactions to obtain the stoichiometric ratio of the reactants and optimum conditions to develop the best color and to select the suitable wavelength for microdetermination of

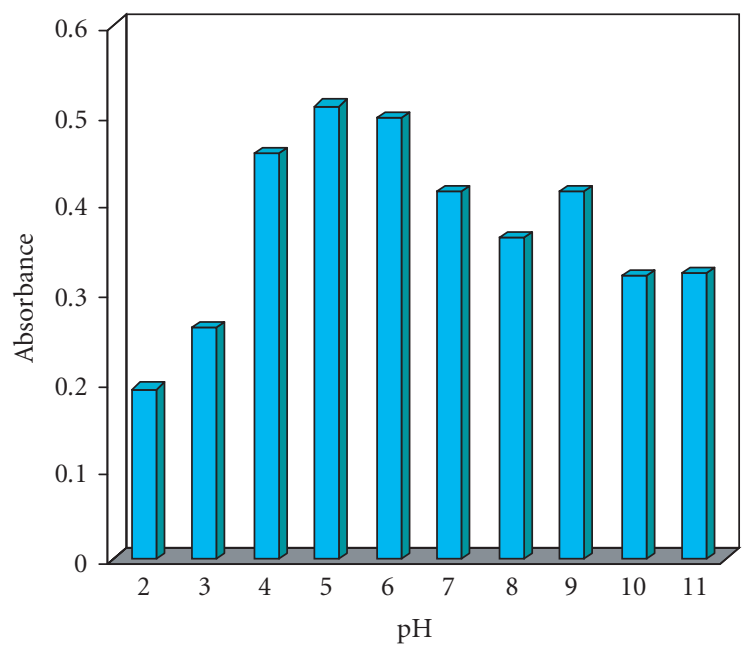

FIGURE 5. Clustered column showing relation between $\mathrm{pH}$ and absorbance in case of $\mathrm{LD}$ with iodine compound at wavelength $=500 \mathrm{~nm}$.

LD. The low oxidation potential of the iodine reaction makes it much more selective than the other oxidizing agents [17].

The selected optimum $\mathrm{pH}$ using universal buffer ( $\mathrm{pH}$ range 2-12) is 5 at maximum wavelength $500 \mathrm{~nm}$ (Figure 5). The most suitable ratio of $\left[\mathrm{I}_{3}^{-}\right]$: [LD] was found to be $3: 2$. The required time for the completeness of the reaction between the $\mathrm{I}_{3}^{-}$ion and $\mathrm{LD}$ was found to be 6 minutes (Figure 6) which is sufficient where the absorbance is maximal and remains constant. The effect of temperature was studied in the temperature range $10-60^{\circ} \mathrm{C}$ (Figure 7 ) and it was found that, for 


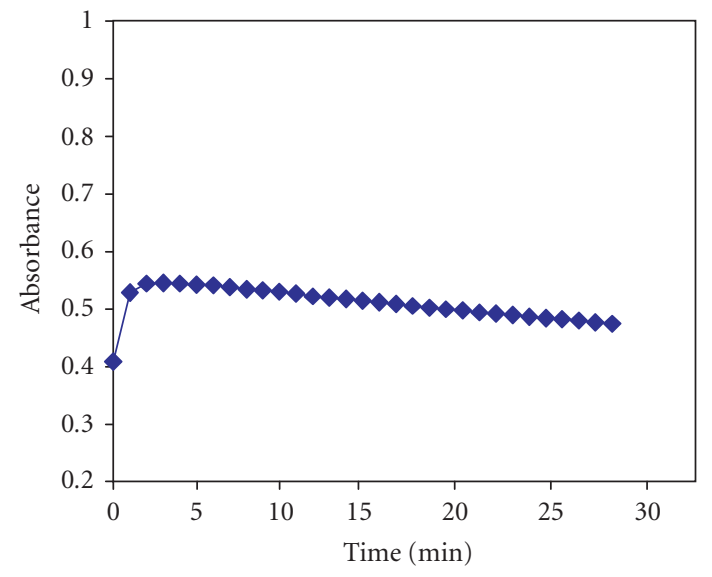

FiguRE 6. Effect of time on the absorbance of LD-iodine compound, at $\mathrm{pH}=5$ and at wavelength $=500 \mathrm{~nm}$.

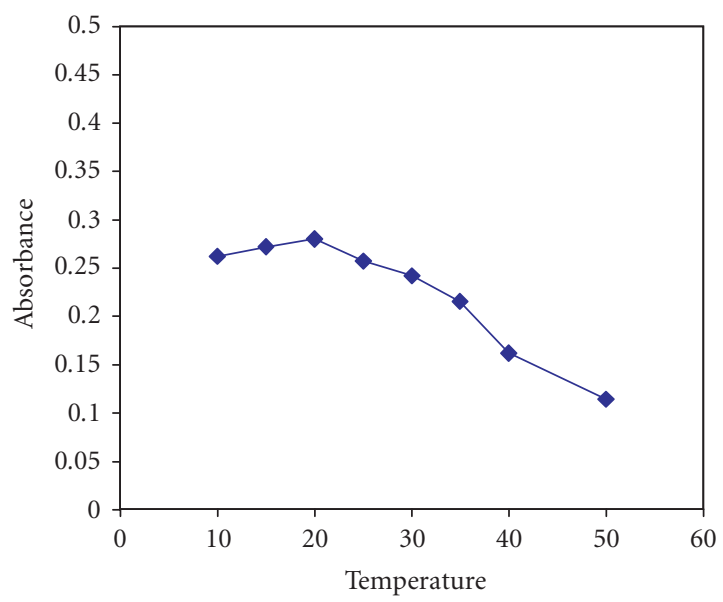

FIGURE 7. Effect of temperature on the absorbance of LD-iodine compound at wavelength $=500 \mathrm{~nm}$.

microdetermination of $\mathrm{LD}$, it is preferable to adjust the temperature at $\left(23 \pm 2^{\circ} \mathrm{C}\right)$. $\mathrm{LD}$ can be determined in the concentration range of $39.44-78.88 \mu \mathrm{g} \mathrm{mL}^{-1}$. The standard deviation and relative standard deviation values were found to be $0.239 \%$ and $0.54 \%$, respectively (Table 1 ). The apparent molar absorptivity and Sandell sensitivity of the resulting colored product were found to be $5.1 \times 10^{3}$ and $0.026 \mathrm{~g} \mathrm{~cm}^{-2}$, respectively. The values of these parameters (Table 1) can be considered satisfactory at least for the drugs concentration levels examined.

\section{Interference}

Several pharmaceutical preparations are associated with flavoring agents, diluents and excipients. Table 2 shows the effect of organic interfering materials that may be present in pharmaceutical preparations such as glucose, maltose, 2-nitrophenol, phenol, pyrogallol, resorcinol, and pyrocatechol on the reaction of $\mathrm{Cu}$ (II) com- plex and 4-AAP and on the reaction of $\mathrm{I}_{3}^{-}$with LD. It was observed that glucose and maltose as carbohydrates are slightly interfered with when each of them is present in 10-folds in the solution mixture. Therefore tablet fillers such as glucose and maltose, which can represent a source of interference in other methods, do not interfere in the proposed method. Other interfering materials (2-nitrophenol, phenol, pyrogallol, resorcinol, and pyrocatechol) were found to have interfering effects. Since $\mathrm{LD}$ as a catecholamine is present in urine samples, the effects of different interfering materials (such as urea, paracetamol, ascorbic acid, and salicylic acid) were tested during microdetermination of LD using our proposed procedure (Table 3). It was obvious that the equimolar amount from urea or 1 fold of salicylic or ascorbic acid has a slight interference that can be neglected, and the mixture of urea and salicylic acid showed slight error in percent recovery for LD. Whereas, with paracetamol or 10 folds from ascorbic acid showing high interference with high percent error in detection.

\section{Determination of LD in LD-CD synthetic mixtures}

In order to prove the applicability to determine LD in some pharmaceutical forms like Levocare, synthetic mixtures containing $\mathrm{LD}$ and $\mathrm{CD}$ were prepared and analyzed for LD determination (procedures (I) and (II)). In these mixtures, the percent recovery of LD ranged from $94 \%$ to $98.8 \%$. These data reflect the high availability of these procedures for microdetermination of LD in presence of CD. From the data it is observed that procedure (II) is highly selective for LD microdetermination in Levocare where it gives percent error of $0.91 \%$.

\section{Determination of LD in pharmaceutical forms}

The proposed methods were applied satisfactorily to the determination of LD in pharmaceutical preparation. Levocare drug contains $250 \mathrm{mg} \mathrm{LD}$ and $25 \mathrm{mg}$ CD in each tablet as an active material. The determination of LD is applied using both methods (Table 4) with percent errors of $4.4 \%$ and $0.91 \%$ for methods (I) and (II), respectively, that can be neglected where present within the internationally acceptable range of errors for pharmaceutical determination.

\section{Determination of $L D$ in biological samples}

Urine and blood samples of normal and abnormal people usually contain many catecholamines. The biological samples are very sensitive and must be collected and stored under optimum conditions to prevent any loss of catecholamines or change its nature [18]. LD is one of the important catecholamine derivatives that can be detected in the urine samples of schizophrenic patients because of its high concentration. Therefore LD concentration was determined in urine of normal and permanently schizophrenic subjects using copper (II) complex and 4-AAP for the sake of comparison. The schizophrenic patients' samples are characterized by high availability 
TABLE 2. Tolerance of organic compounds in spectrophotometric determination of LD. [LD] $=2 \times 10^{-4} \mathrm{M},[\mathrm{Cu}(\mathrm{II})]=0.1 \mathrm{M},[4-\mathrm{AAP}]$ $=0.0295 \mathrm{M},\left[\mathrm{I}_{3}^{-}\right]=0.1 \mathrm{M}$, [tolerance $]=2 \times 10^{-4} \mathrm{M}(1$-fold $)$ and $2 \times 10^{-3} \mathrm{M}(10$-fold $), \mathrm{pH}=10.5, \mathrm{t}=10$ minutes and $\lambda=525 \mathrm{~nm}$.

\begin{tabular}{|c|c|c|c|c|c|c|c|c|c|}
\hline \multirow{3}{*}{$\begin{array}{l}\text { Organic } \\
\text { tolerant } \\
\text { added }\end{array}$} & \multirow{3}{*}{ Fold } & \multirow{2}{*}{\multicolumn{2}{|c|}{$\begin{array}{c}\text { Absorbance } \\
\text { Procedures }\end{array}$}} & \multicolumn{3}{|c|}{ Procedure (I) } & \multicolumn{3}{|c|}{ Procedure (II) } \\
\hline & & & & \multirow{2}{*}{$\begin{array}{c}\text { Taken } \\
(\mu \mathrm{g} \backslash \mathrm{mL})\end{array}$} & \multirow{2}{*}{$\begin{array}{l}\text { Found } \\
(\mu \mathrm{g} \backslash \mathrm{mL})\end{array}$} & \multirow{2}{*}{ Recovery \% } & \multirow{2}{*}{$\begin{array}{c}\text { Taken } \\
(\mu \mathrm{g} \backslash \mathrm{mL})\end{array}$} & \multirow{2}{*}{$\begin{array}{l}\text { Found } \\
(\mu \mathrm{g} \backslash \mathrm{mL})\end{array}$} & \multirow{2}{*}{ Recovery \% } \\
\hline & & (I) & (II) & & & & & & \\
\hline - & - & 0.69 & 0.64 & 39.44 & 39.51 & 100.2 & 59.16 & 60.06 & 101.5 \\
\hline Glucose & 10 & 0.66 & 0.64 & 39.44 & 37.62 & 95.39 & 59.16 & 59.75 & 101.5 \\
\hline Maltose & 10 & 0.70 & 0.63 & 39.44 & 40.19 & 101.9 & 59.16 & 58.97 & 99.68 \\
\hline \multirow{2}{*}{ 2-nitrophenol } & 10 & Out of scale & 0.64 & - & - & - & 59.16 & 60.02 & 101.4 \\
\hline & 1 & 0.80 & - & 39.44 & 46.61 & 118 & - & - & - \\
\hline \multirow{2}{*}{ Phenol } & 10 & Out of scale & 0.60 & - & - & - & 59.16 & 54.28 & 91.75 \\
\hline & 1 & - & 0.62 & - & - & - & 59.16 & 57.88 & 97.84 \\
\hline Pyrogallol & 10 & 1.68 & 0.34 & 39.44 & 106.6 & 270 & 59.16 & 13.66 & 23.10 \\
\hline Resorcinol & 10 & Out of scale & 0.57 & - & - & - & 59.16 & 48.81 & 82.50 \\
\hline \multirow{2}{*}{ Pyrocatechol } & 10 & Out of scale & 0.55 & - & - & - & 59.16 & 46.47 & 78.55 \\
\hline & 1 & 1.09 & 0.75 & 39.44 & 66.68 & 169 & 59.16 & 76.94 & 130.0 \\
\hline
\end{tabular}

TABLE 3. Effect of common tolerances that may be present in the urine sample with LD using copper tetramine complex and 4-AAP. $[\mathrm{LD}]=2 \times 10^{-4} \mathrm{M}$, [tolerance $]=2 \times 10^{-4} \mathrm{M},\left[\mathrm{Cu}^{+2}\right]=0.1 \mathrm{M},[4-\mathrm{AAP}]=0.0295 \mathrm{M}, \mathrm{pH}=10.5, \mathrm{t}=10$ minutes, $\lambda=525 \mathrm{~nm}$.

\begin{tabular}{|c|c|c|c|c|}
\hline Tolerant added & Fold & Taken $(\mu \mathrm{g} \backslash \mathrm{mL})$ & Found $(\mu \mathrm{g} \backslash \mathrm{mL})$ & Recovery \% \\
\hline - & - & 39.44 & - & 100 \\
\hline \multirow{2}{*}{ Urea } & 1 & & 39.22 & 99.44 \\
\hline & 10 & 39.44 & 38.34 & 97.21 \\
\hline \multirow{2}{*}{ Salicylic acid } & 1 & & 39.22 & 99.44 \\
\hline & 10 & 39.44 & 44.47 & 112.7 \\
\hline \multirow{2}{*}{ Paracetamol } & 1 & & 64.09 & 162.5 \\
\hline & 10 & 39.44 & Out of scale & - \\
\hline \multirow{2}{*}{ Ascorbic acid } & 1 & & 36.93 & 93.64 \\
\hline & 10 & 39.44 & No absorbance & - \\
\hline Urea + salicylic acid & 1 & 39.44 & 37.96 & 96.25 \\
\hline
\end{tabular}

TABLE 4. Microdetermination of LD in pharmaceutical form using copper (II) complex and 4-AAP and LD with $\mathrm{I}_{3}^{-}$.

\begin{tabular}{|c|c|c|c|c|c|c|c|c|c|c|}
\hline \multirow{2}{*}{ Drug } & \multicolumn{2}{|c|}{ Procedure $(\mathrm{I})(\mu \mathrm{g} \backslash \mathrm{mL})$} & \multirow{2}{*}{$\mathrm{SD}^{*}$} & \multirow{2}{*}{$\mathrm{CV}^{*}$} & \multirow{2}{*}{ Error $\#$} & \multicolumn{2}{|c|}{ Procedure (II) $(\mu \mathrm{g} \backslash \mathrm{mL})$} & \multirow{2}{*}{$\mathrm{SD}^{*}$} & \multirow{2}{*}{$\mathrm{CV}^{*}$} & \multirow{2}{*}{ Error ${ }^{\#} \%$} \\
\hline & Taken & Found & & & & Taken & Found & & & \\
\hline \multirow[t]{4}{*}{ Levocar } & 35.01 & 36.02 & 0.65 & 1.8 & & 37.51 & 38.34 & 0.74 & 1.9 & \\
\hline & 45.01 & 46.12 & 0.55 & 1.10 & & 45.00 & 44.903 & 0.65 & 1.25 & \\
\hline & 50.00 & 51.94 & 0.45 & 0.87 & & 50.00 & 49.24 & 0.19 & 0.39 & \\
\hline & & & & & 4.39 & & & & & 0.91 \\
\hline
\end{tabular}

* Number of replicates are 3-5.

\#Average error.

of dopamine secretion that can be more easily detected in urine than in plasma. The type of medication in these cases depends on decreasing dopamine secretion by blocking dopamine receptors in the brain using haloperidol, Neurazine, Medicate, Promacide and Tegretol-T, for example. From Table 5 it is obvious that there are three urine samples which were collected from each of the five permanently schizophrenic patient under medication. The concentration of LD in urine samples collected before and after one and two hours from drug administration nearly reached normal values in the case of patients $1,2,3$, and 4 when compared to normal people $\left(32-36 \mu \mathrm{g} \mathrm{mL}^{-1}\right)$. It can also be concluded that the type of medication in these cases is highly effective and can be continued. 
TABLE 5. Determination of LD in the urine samples of schizophrenic patients using copper (II) complex and 4-AAP under selected and optimum $\mathrm{pH}$, temperature, time, and wavelength.

\begin{tabular}{|c|c|c|c|c|c|c|}
\hline \multirow{2}{*}{ Patients } & \multirow{2}{*}{ Age (years) } & \multirow{2}{*}{ History } & \multicolumn{2}{|c|}{ Medication } & \multicolumn{2}{|c|}{ Concentration } \\
\hline & & & Name & Dose & & \\
\hline \multirow{3}{*}{1 Male } & \multirow{3}{*}{41} & \multirow{3}{*}{$\begin{array}{l}\text { Chronic schizophrenia } \\
\text { for } 20 \text { years. Began his } \\
\text { treatment } 2 \text { months ago. }\end{array}$} & \multirow{3}{*}{$\begin{array}{l}\text { Halloperidol } \\
\text { (tablet) }\end{array}$} & \multirow{3}{*}{$\begin{array}{c}15 \mathrm{mg} / \mathrm{d} \\
(5 \mathrm{mg} \text { every } 8 \text { hours })\end{array}$} & $*$ & 30.79 \\
\hline & & & & & $* *$ & 28.26 \\
\hline & & & & & $* * *$ & 21.50 \\
\hline \multirow{3}{*}{2 Males } & \multirow{3}{*}{58} & \multirow{3}{*}{$\begin{array}{l}\text { Residual schizophrenia } \\
\text { for } 25 \text { years }\end{array}$} & \multirow{3}{*}{$\begin{array}{l}\text { Neurazine } \\
\text { (tablet) }\end{array}$} & \multirow{3}{*}{$\begin{array}{c}100 \mathrm{mg} / \mathrm{d} \\
\text { (one tablet per day) }\end{array}$} & $*$ & 29.42 \\
\hline & & & & & $* *$ & 18.46 \\
\hline & & & & & $* * *$ & 27.83 \\
\hline \multirow{3}{*}{3 Males } & \multirow{3}{*}{52} & \multirow{3}{*}{$\begin{array}{l}\text { Chronic schizophrenia } \\
\text { for } 20 \text { years }\end{array}$} & \multirow{3}{*}{$\begin{array}{l}\text { Modicate } \\
\text { (ampoules) } \\
\text { Millerile } \\
\text { (tablet) }\end{array}$} & \multirow{3}{*}{$\begin{array}{c}25 \mathrm{mg} \\
\text { (every two weeks) } \\
200 \mathrm{mg} \\
\text { (two doses daily) }\end{array}$} & $*$ & 39.13 \\
\hline & & & & & $* *$ & 34.45 \\
\hline & & & & & $* * *$ & 16.78 \\
\hline \multirow{3}{*}{4 Males } & \multirow{3}{*}{46} & \multirow{3}{*}{$\begin{array}{l}\text { Residual schizophrenia } \\
\text { for } 16 \text { years }\end{array}$} & \multirow{3}{*}{$\begin{array}{l}\text { Neurazine } \\
\text { (tablet) } \\
\text { Safinase } \\
\text { (tablet) }\end{array}$} & \multirow{3}{*}{$\begin{array}{c}100 \mathrm{mg} \\
\text { (two doses daily) } \\
5 \mathrm{mg} \\
\text { (two doses daily) }\end{array}$} & $*$ & 27.86 \\
\hline & & & & & $* *$ & 34.47 \\
\hline & & & & & $* * *$ & 42.82 \\
\hline \multirow{3}{*}{5 Males } & \multirow{3}{*}{49} & \multirow{3}{*}{$\begin{array}{l}\text { Residual Schizophrenia } \\
\text { for } 25 \text { years }\end{array}$} & $\begin{array}{c}\text { Modicate } \\
\text { (ampoules) }\end{array}$ & $\begin{array}{c}25 \mathrm{mg} \\
\text { (every two weeks) }\end{array}$ & $*$ & 106.08 \\
\hline & & & $\begin{array}{l}\text { Promacide } \\
\text { (tablet) }\end{array}$ & $\begin{array}{c}100 \mathrm{mg} \\
\text { (two doses daily) }\end{array}$ & $* *$ & 98.77 \\
\hline & & & $\begin{array}{l}\text { Tegretol } \\
\text { (tablet) }\end{array}$ & $\begin{array}{c}200 \mathrm{mg} \\
\text { (two doses daily) }\end{array}$ & $* * *$ & 79.51 \\
\hline
\end{tabular}

* Before drug administration.

$* *$ One hour after drug administration.

$* * *$ Two hours after drug administration.

In Table 4, it is observed that there is an exception in the case of patient 5 , where the concentrations of LD in urine one hour and two hours before and after drug administration are $106,98.8$, and $79.5 \mu \mathrm{g} \mathrm{mL}^{-1}$, respectively. This indicates that there is no responsiveness of patient 5 to the type of medication, which must be changed or rearranged. On discussing this point with a physician, he represented his agreement with our notes that patient 5 had not improved as expected and the medication must be rearranged to decrease the concentration of LD to bring it as close as possible to the normal value.

On comparison of the results obtained by the proposed methods, (I) and (II), with those obtained by the pharmaceutical method [19] using the $t$ test for accuracy and F test for precision [20], the calculated values did not exceed the corresponding theoretical values (tabulated values of $t$ and $\mathrm{F}$ tests under confidence limit $95 \%=2.62-2.776$ and $6.58-6.78$, respectively) indicating insignificant differences between the results and also referring to the robustness of the proposed procedures. The proposed procedures are more accurate and of high robustness, with high recoveries amounting to 98.70 $99.66 \pm 0.6 \%$ compared with 99.6 to $99.9 \pm 1.6 \%$ of the pharmaceutical method.

\section{CONCLUSION}

The methods proposed for the estimation of LD and CD are advantageous over many reported methods. This may be attributed to their sensitivity, rapidity, noninterference with other ingredients usually present in pharmaceutical preparations and urine samples, precision and good agreement with the official method. Hence these two methods can be used for the routine analyses.

\section{ACKNOWLEDGMENT}

Many thanks to Dr. Ahmed G. El-Nahas (Psychatric Specialist) for help and for his big effort. The publication of this work was supported by the Open Society Institute (OSI) under Grant no. I8527.

\section{REFERENCES}

[1] Rodriguez MC, Obeso JA, Olanow CW. Subthalamic nucleus-mediated excitotoxicity in Parkinson's disease: a target for neuroprotection. Ann Neurol. 1998;44(suppl 3):S175-S188. 
[2] Uhl GR, Kitayama S. A cloned dopamine transporter. Potential insights into Parkinson's disease pathogenesis. Adv Neurol. 1993;60:321-324.

[3] Kaakkola S, Tuomainen P, Wurtman RJ, Mannisto PT. Effects of systemic carbidopa on dopamine synthesis in rat hypothalamus and striatum. J Neural Transm Park Dis Dement Sect. 1992;4(2):143-154.

[4] Mannisto PT, Ulmanen I, Lundstrom K, et al. Characteristics of catechol $\mathrm{O}$-methyl-transferase (COMT) and properties of selective COMT inhibitors. Prog Drug Res. 1992;39:291-350.

[5] El-Kommos ME, Mohamed FA, Khedr AS. Spectrophotometric determination of some catecholamine drugs using metaperiodate. J Assoc Off Anal Chem. 1990;73(4):516-520.

[6] Nagaraja P, Murthy KCS, Rangappa KS, Gowda NMM. Spectrophotometric methods for the determination of certain catecholamine derivatives in pharmaceutical preparations. Talanta. 1998;46(1): 39-44.

[7] Vuorensola K, Siren H, Karjalainen U. Determination of dopamine and methoxycatecholamines in patient urine by liquid chromatography with electrochemical detection and by capillary electrophoresis coupled with spectrophotometry and mass spectrometry. J Chromatogr B Analyt Technol Biomed Life Sci. 2003;788(2):277-289.

[8] Zhang W, Xie Y, Ai S, et al. Liquid chromatography with amperometric detection using functionalized multi-wall carbon nanotube modified electrode for the determination of monoamine neurotransmitters and their metabolites. J Chromatogr B Analyt Technol Biomed Life Sci. 2003;791(1-2):217-225.

[9] Uslu B, Özkan S. Determination of binary mixtures of levodopa and benserazide in pharmaceuticals by ratio-spectra derivative spectrophotometry. Anal Lett. 2002;35(2):303-314.

[10] Zhang L, Zhao WK. Solvent extraction and high performance liquid chromatography with electrochemical detection for determination of plasma catecholamines. Zhongguo Yao Li Xue Bao. 1989;10(6):572-575 [in Chinese].

[11] Gowenlock AH, McMurray JR, McLauchlan DM, eds. Varley's Practical Clinical Biochemistry. 6th ed. London: Heinemann Medical Books; 1988.

[12] Reynolds JEF, ed. Martindale: The Extra Pharmacopoeia. 28th ed. London: Pharmaceutical Press; 1982.

[13] Nukatsuka I, Nakamura S, Watanabe K, Ohzeki K. Determination of phenol in tap water and river water samples by solid-phase spectrophotometry. Anal Sci. 2000;16(3):269-273.

[14] Kang C, Wang Y, Li R, et al. A modified spectrophotometric method for the determination of trace amounts of phenol in water. Microchem J. 2000;64(2):161-171.

[15] Mohamed GG, Zayed MA, Nour El-Dien FA, ElNahas RG. IR, UV-Vis, magnetic and thermal char- acterization of chelates of some catecholamines and 4-aminoantipyrine with $\mathrm{Fe}(\mathrm{III})$ and $\mathrm{Cu}(\mathrm{II})$. Spectrochimica Acta Part A: Molecular and Biomolecular Spectroscopy. 2004;60(8-9):1775-1781.

[16] Nour El-Dien FA. Analytical and physical studies on the reaction of iodine, iodate and periodate as oxidants with some phenol derivatives and reductants $[\mathrm{PhD}$ thesis]. Cairo, Egypt: Cairo University; 1985.

[17] Rashwan NAA. Analytical studies on reaction of Iodine and some iron (III) chelates with some phenolic compounds [MS thesis]. Cairo, Egypt: Cairo University; 1992.

[18] Boomsma F, Alberts G, van Eijk L, Man in 't Veld AJ, Schalekamp MA. Optimal collection and storage conditions for catecholamine measurements in human plasma and urine. Clin Chem. 1993;39(12):2503-2508.

[19] British Pharmacological Society. British Pharmacopoeia 1998. London, UK: Stationery Office Books; 1998.

[20] Miller JC, Miller JN. Statistics for Analytical Chemistry. 2nd ed. Chichester: Ellis Horwood; 1988.

* Corresponding author. E-mail: reham_elnahas1711@yahoo.com Tel: +2 022607782 

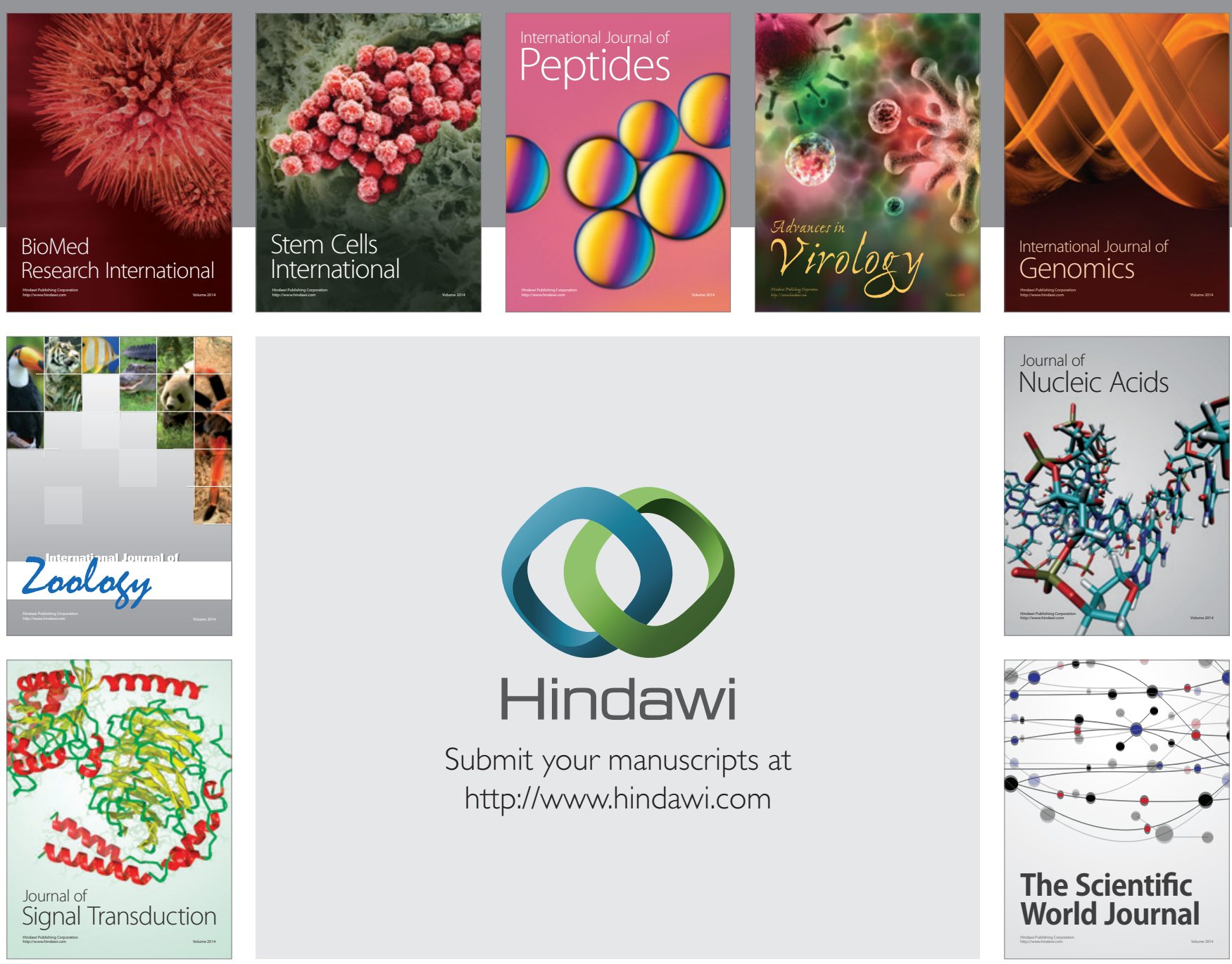

Submit your manuscripts at

http://www.hindawi.com
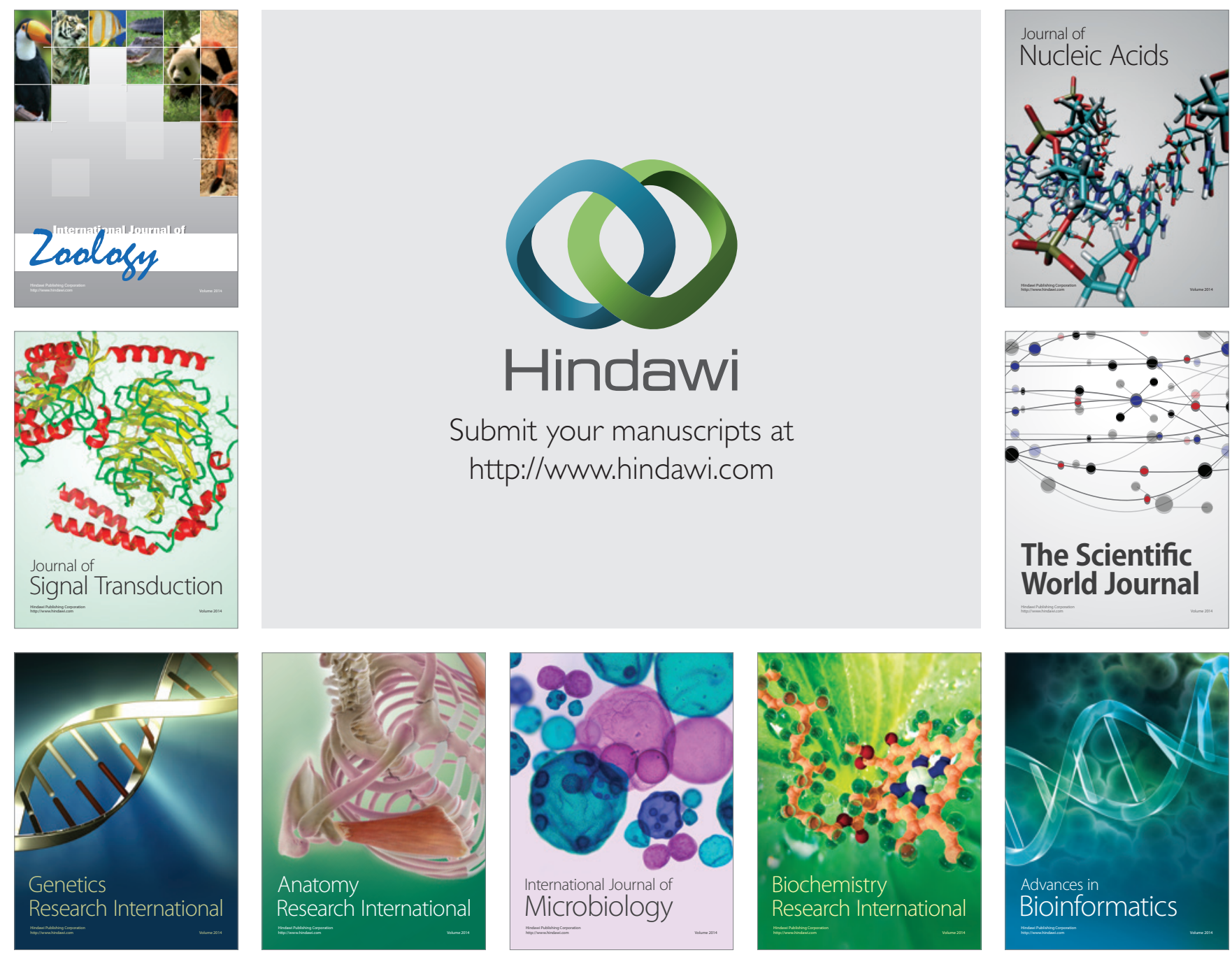

The Scientific World Journal
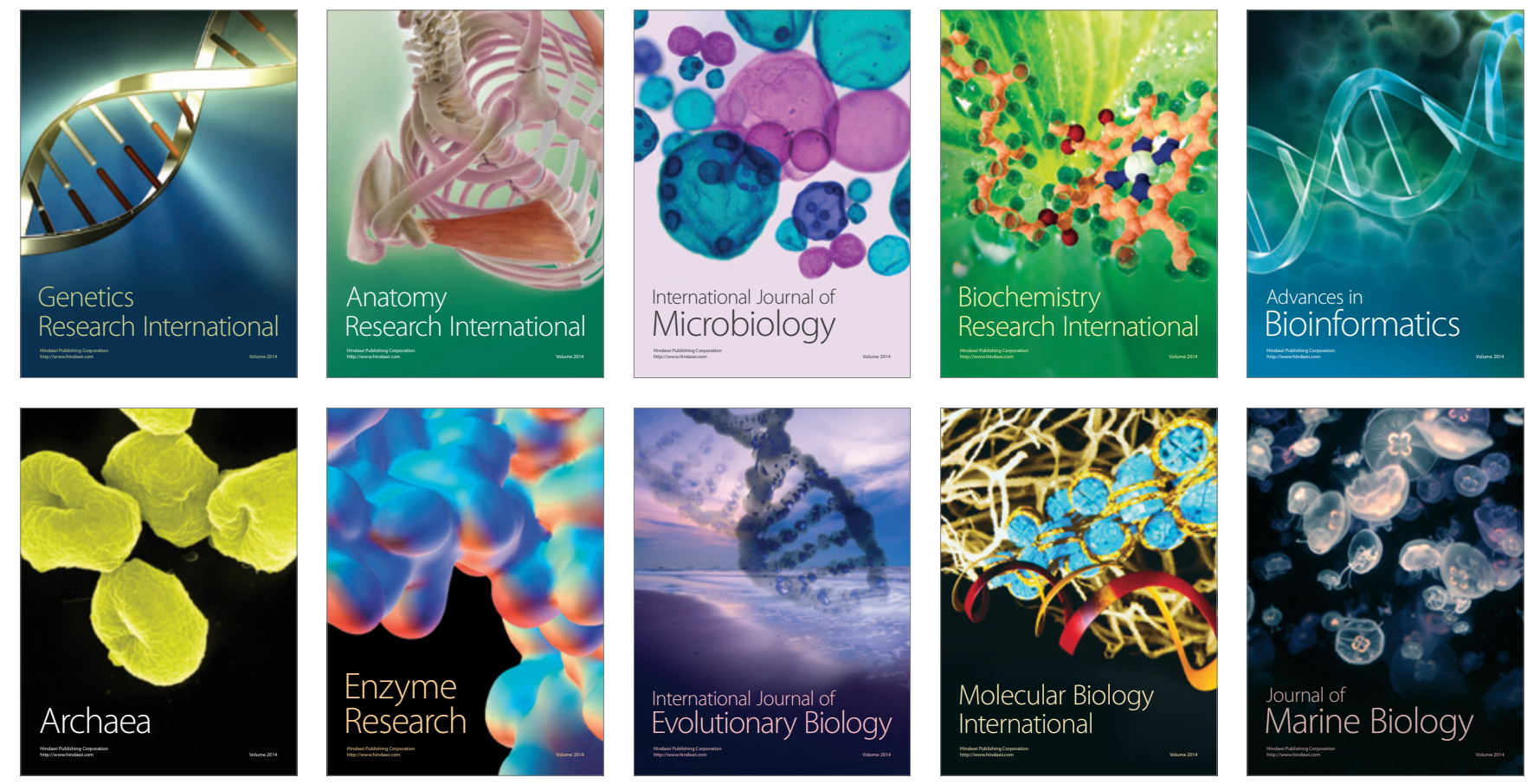